\title{
Paraneoplastic recurrent tumefactive demyelination in a 62-year-old man with metastatic seminoma
}

Simon Thebault, Ilana Hanes, John Woulfe, and Pierre R. Bourque

Neurol Neuroimmunol Neuroinflamm 2019;6:e527. doi:10.1212/NXI.0000000000000527

\author{
Correspondence \\ Dr. Thebault \\ sthebault@toh.on.ca
}

A 62-year-old man presented with subacutely progressive headache, right-sided weakness, and subtle receptive aphasia. The initial MRI showed a large oval subcortical left frontoparietal lesion, hypertintense on T2- and hypointense on T1-weighted sequences, exerting mass effect on adjacent sulci (figure, A). This lesion, which had a thin rim of peripheral diffusion restriction, and showed only minimal focal enhancement, was favored to represent a low-grade glioma. The patient was admitted to a neurosurgical service, and treated with high-dose dexamethasone, which resulted in partial clinical improvement before open craniotomy and a limited debulking resection. He did well postoperatively and was discharged with only mild right hemisensory loss. Unexpectedly, histopathology showed no evidence of neoplasia. There was demyelination and inflammatory infiltration with a predominance of CD68-immunoreactive foamy reactive macrophages (figure, B). CSF examination (cell counts, protein, and albumin index) was normal, without evidence of oligoclonal bands. The neurology consultant favored a diagnosis of isolated tumefactive demyelinating lesion, lacking MS criteria for clinical or imaging evidence of dissemination in time and space. No further treatment was recommended initially because deficits were minor and improving.

Two-months later, the patient was readmitted with a 5-day history of progressive new right-sided weakness, sensory loss, receptive aphasia, and right homonymous hemianopia. Empirical high-dose daily IV methylprednisolone was started. A repeat MRI showed a new extensive pattern of T2 signal abnormality extending from the surgical cavity to deeper ipsilateral structures, including the internal capsule, thalamus, cerebral peduncle, and pons. There was only minimal mass effect and focal gadolinium enhancement, which did not surround the lesion (figure, C). MRI spectroscopy within the lesion showed an NAA/choline ratio of 0.42 with a lipid lactate peak suggestive of a nontumoral process, such as necrosis or inflammatory demyelination. The differential diagnosis however included CNS lymphoma and progressive multifocal leucoencephalopathy. Whole-body CT revealed a 5-cm para-aortic mass at the mid-lumbar level, suggestive of metastatic adenopathy. A core needle biopsy of the mass showed highly atypical cells with prominent nucleoli, staining positively for SALL4 and OCT3/4 and negatively for CD30. This was consistent with metastatic seminoma (figure). Testicular ultrasound revealed that the left testis had an irregular contour with areas of hypoechogenicity and calcifications. Orchiectomy histopathology confirmed extensive atrophy and focal fibrosis, suggestive of a "burned out" germ cell tumor. A dedicated pathologic re-examination of the brain failed to show any evidence of germ cell infiltration. The patient's serum and CSF were sent for cell-based assay testing of clinically relevant paraneoplastic antibodies (including anti-Ma2/ $\mathrm{Ta}$ ) and cell-surface neuronal, myelin, and astrocyte antibodies (including anti-aquaporin- 4 and anti-MOG); all were negative. Further screening by immunofluorescence immunohistochemistry of rat brain sections and on live neuronal cultures did not reveal specific binding.

The oncologic diagnosis was stage IIb seminoma, which was treated with radiotherapy to the para-aortic region. After bolus methylprednisolone, the patient was treated with a slow tapering

From the Ottawa Hospital, Division of Neurology (S.T., P.R.B.); The Children's Hospital of Eastern Ontario (I.H.); The Ottawa Hospital (J.W.), Department of Pathology and Laboratory Medicine; and The Ottawa Hospital Research Institute (P.R.B.), ON, Canada.

Funding information and disclosures are provided at the end of the article. Full disclosure form information provided by the authors is available with the full text of this article at Neurology.org/NN.

The Article Processing Charge was funded by the authors.

This is an open access article distributed under the terms of the Creative Commons Attribution-NonCommercial-NoDerivatives License 4.0 (CC BY-NC-ND), which permits downloading and sharing the work provided it is properly cited. The work cannot be changed in any way or used commercially without permission from the journal. 


\section{Figure Images}
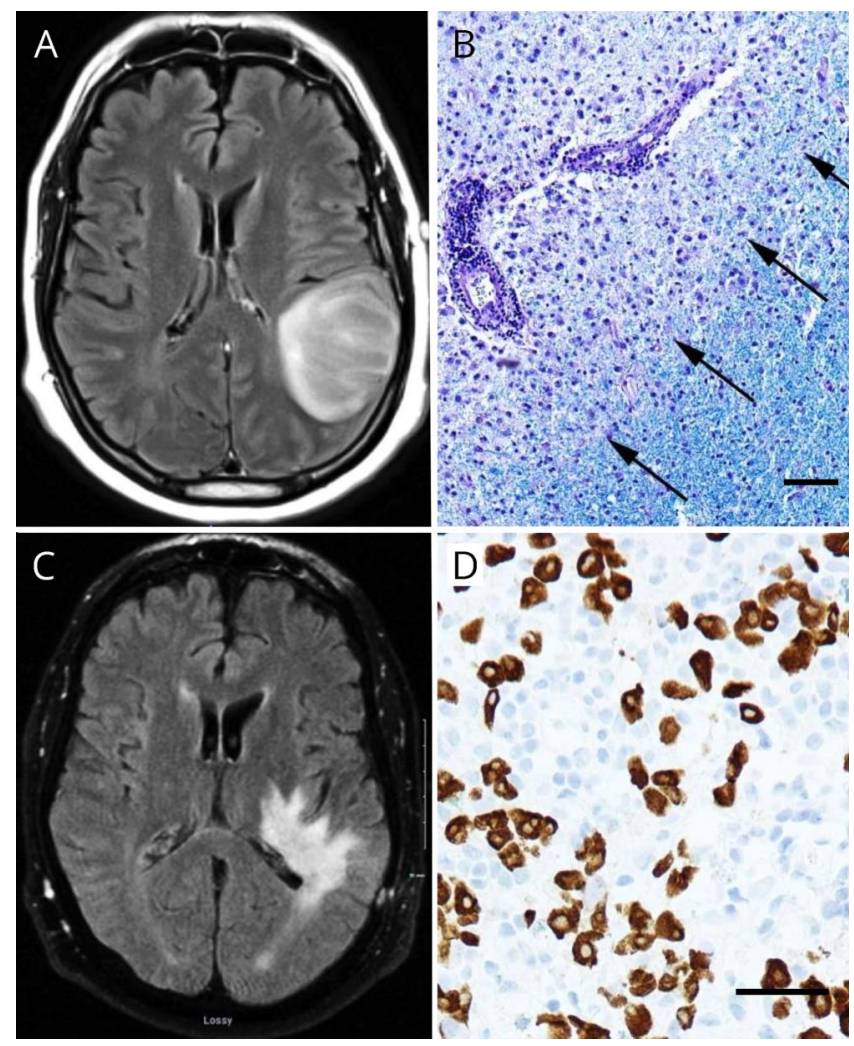

(A) Left frontoparietal "mass" (T2 FLAIR). (B) Histopathologic demyelination (Luxol fast blue/periodic acid Schiff), macrophage infiltration, and relative preservation of axons (not shown). (C) Two months later, extensive T2 hyperintensity (T2 FLAIR) believed to represent atypical demyelination. (D) Workup revealed a retroperitoneal mass, with histology positive for germ cell markers SALL-4 (shown) and OCT-3/4 (not shown). Bars $=50 \mu \mathrm{M}$.

course of oral steroids for the brain lesion. Ten months after initial symptomatic onset, he had marked improvement in visual and language deficits but persistent severe right hemiparesis, affecting the leg more than the arm. The last MRI showed overall marked improvement in the abnormal signal noted in the left temporal, parietal, and brainstem regions, with residual changes most prominently in the thalamus and splenium of the corpus callosum.

This is the fourth report of paraneoplastic tumefactive demyelination with seminoma, ${ }^{1-3}$ excluding 1 report in which autopsy showed definite additional intravascular seminoma. ${ }^{4}$ Although unrevealing, this is the first reported search for autoantibodies in a possible new paraneoplastic entity. In all 3 previous cases, the neurologic syndrome was the index manifestation and consisted of visual and memory deficits. MRI showed lesions restricted to occipital lobes and posterior corpus callosum. Two patients had permanent neurologic sequelae despite treatment with steroids and chemotherapy. Our case showed unique prominent unilateral spread of demyelination to subcortical structures including the thalamus and brainstem. Distinguishing tumefactive demyelination from glioma or lymphoma on imaging remains challenging.
The following features may favor demyelination: incomplete rim enhancement, $\mathrm{T} 2$ hypointense rim, absent or mild mass effect, and minimal perilesional edema. ${ }^{5,6}$ This is also another example of "burned out" testicular seminoma, ${ }^{7}$ in which testicular imaging and biopsy may seem unrevealing, and metastatic germ cell tumor is only revealed by dedicated systemic imaging. Although seminomas mostly respond well to chemotherapy and radiotherapy, with favorable long-term survival rates, the occurrence of tumefactive demyelination seems to be associated with less favorable functional outcome.

\section{Acknowledgments}

The authors thank the University of Oxford Neuroimmunology laboratory for performing immunohistochemistry and live neuronal antibody screens.

\section{Study funding}

No targeted funding.

\section{Disclosure}

S. Thebault and I. Hanes report no disclosures; J. Woulfe received research support from the Canadian Institutes of Health Research and Partners Investing in Parkinson Research. P. Bourque reports no disclosures. Full disclosure form information provided by the authors is available with the full text of this article at Neurology.org/NN.

\section{Publication history}

Received by Neurology: Neuroimmunology \& Neuroinflammation August 15, 2018. Accepted in final form October 17, 2018.

\section{Appendix 1 Author contributions}

\begin{tabular}{llll}
\hline Name & Location & Role & Contribution \\
\hline $\begin{array}{l}\text { Simon } \\
\text { Thebault }\end{array}$ & $\begin{array}{l}\text { University } \\
\text { of Ottawa }\end{array}$ & Author & $\begin{array}{l}\text { Conceptualization, MRI compilation, } \\
\text { and manuscript preparation }\end{array}$ \\
\hline $\begin{array}{l}\text { Ilana } \\
\text { Hanes }\end{array}$ & $\begin{array}{l}\text { University } \\
\text { of Ottawa }\end{array}$ & Author & Assisted in write-up \\
\hline $\begin{array}{l}\text { John } \\
\text { Woulfe }\end{array}$ & $\begin{array}{l}\text { University } \\
\text { of Ottawa }\end{array}$ & Author & Pathologic data compilation \\
\hline $\begin{array}{l}\text { Pierre } \\
\text { Bourque }\end{array}$ & $\begin{array}{l}\text { University } \\
\text { of Ottawa }\end{array}$ & Author & $\begin{array}{l}\text { Conceptualization and oversight and } \\
\text { manuscript and imaging review }\end{array}$ \\
\hline
\end{tabular}

\section{References}

1. Broadfoot JR, Archer HA, Coulthard E, et al. Paraneoplastic tumefactive demyelination with underlying combined germ cell cancer. Pract Neurol 2015;15: 451-455.

2. Wong K, Poon P, Berry K, Coppin C, Kostashuk E. Paraneoplastic demyelinating disorder in the brain of a patient with seminoma. J Comput Assist Tomogr 1998;22: 136-138.

3. Jaster JH, Bertorini TE, Dohan FC, et al. Solitary focal demyelination in the brain as a paraneoplastic disorder. Med Pediatr Oncol 1996;26:111-115.

4. Kaluza J, Slowinski J, Bujny T, Grochala M. Paraneoplastic syndrome simulating encephalitis in the course of testicular seminoma. Folia neuropathologica 1997;35: 24-28.

5. Suh CH, Kim HS, Jung SC, Choi CG, Kim SJ. MRI findings in tumefactive demyelinating lesions: a systematic review and meta-analysis. AJNR Am J Neuroradio 2018;39:1643-1649.

6. Lucchinetti CF, Gavrilova RH, Metz I, et al. Clinical and radiographic spectrum of pathologically confirmed tumefactive multiple sclerosis. Brain 2008;131:1759-1775.

7. Gurioli A, Oderda M, Vigna D, et al. Two cases of retroperitoneal metastasis from a completely regressed burned-out testicular cancer. Urologia 2013;80:74-79. 


\title{
Neurology \\ Neuroimmunology \& Neuroinflammation
}

\author{
Paraneoplastic recurrent tumefactive demyelination in a 62-year-old man with \\ metastatic seminoma \\ Simon Thebault, Ilana Hanes, John Woulfe, et al. \\ Neurol Neuroimmunol Neuroinflamm 2019;6; \\ DOI 10.1212/NXI.0000000000000527
}

This information is current as of December 13, 2018

\section{Updated Information \& Services}

References

Subspecialty Collections

Permissions \& Licensing

Reprints including high resolution figures, can be found at:

http://nn.neurology.org/content/6/1/e527.full.html

This article cites 7 articles, 2 of which you can access for free at: http://nn.neurology.org/content/6/1/e527.full.html\#\#ref-list-1

This article, along with others on similar topics, appears in the following collection(s):

All Demyelinating disease (CNS)

http://nn.neurology.org//cgi/collection/all_demyelinating_disease_cns Metastatic tumor

http://nn.neurology.org//cgi/collection/metastatic_tumor

MRI

http://nn.neurology.org//cgi/collection/mri

Paraneoplastic syndrome

http://nn.neurology.org//cgi/collection/paraneoplastic_syndrome

Information about reproducing this article in parts (figures,tables) or in its entirety can be found online at:

http://nn.neurology.org/misc/about.xhtml\#permissions

Information about ordering reprints can be found online:

http://nn.neurology.org/misc/addir.xhtml\#reprintsus

Neurol Neuroimmunol Neuroinflamm is an official journal of the American Academy of Neurology.

Published since April 2014, it is an open-access, online-only, continuous publication journal. Copyright

Copyright $(\subseteq 2018$ The Author(s). Published by Wolters Kluwer Health, Inc. on behalf of the American

Academy of Neurology.. All rights reserved. Online ISSN: 2332-7812.

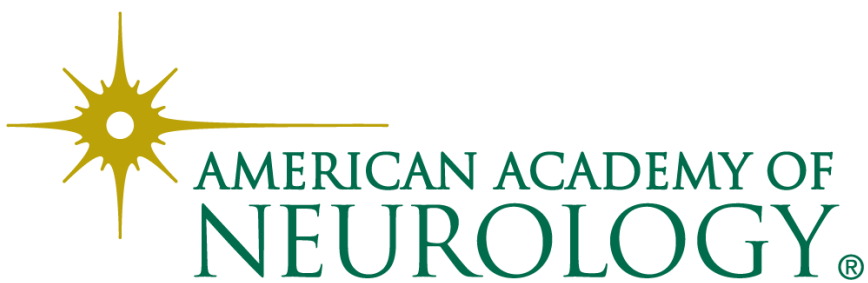

